\title{
Performance of Tunisian Banks Following Transformations of Banking Activities
}

\author{
Bassem Salhi ${ }^{1} \&$ Younes Boujelbene ${ }^{1}$ \\ ${ }^{1}$ Faculty of Economic Science and Management, University of Sfax, Sfax, Tunisia \\ Correspondence: Bassem Salhi, Faculty of Economic Science and Management, Researcher, University of Sfax, \\ Sfax, Tunisia. E-mail: bassem.salhi@yahoo.fr
}

Received: May 12, 2012

doi:10.5539/ijbm.v7n23p31
Accepted: October 15, 2012

Online Published: November 8, 2012

URL: http://dx.doi.org/10.5539/ijbm.v7n23p31

\begin{abstract}
This article aims to study the impact of new forms of banking intermediation on the performance of Tunisian banks. The analysis was conducted on a sample of 10 Tunisian banks for a period of analysis that spans 13 years, from 1997 until 2009. To make better use of our database, we have utilized the panel data technique.

Our empirical validation shows that the context of bank intermediation is still traditional, despite the reforms of financial liberalization; they still carry the traditional business model of collecting deposits and granting loans to increase their profit margins bank.
\end{abstract}

Keywords: new banking intermediation, Tunisian banks, banking performance

JEL Classification: C12, C23, G21

\section{Introduction}

The Tunisian economy was, until 1986, a debt economy characterized by the administration of interest rates through its control of the national bank liquidity and the redirection of loans towards urgent utilizations. Thus, intervention by monetary authorities in the determination of interest rates was complex and resulted in an increase in rates.

The Tunisian central bank sets not only the rediscount rate and the money market to finance day to day, but also that the rates payable as bank lending thereby fixing the banking margin.

An extensive program of restructuring, modernization and consolidation of the banking system was undertaken, with the adoption of a structural adjustment program (SAP) since 1986, to allow Tunisia to become engaged in a process of profound transition. This transition means the transition from a protected and regulated by the state, to an open economy and regulated by the market. As part of the transition, these reforms are accompanied by changes in the financial behavior of economic agents. Some have tended to favor the access to capital markets to finance their borrowing or invest their cash, because these markets are more liquid.

In this context, Allen and Santomero (2001) reported the orientation of banks to market operations. In fact, the traditional activity of banks has changed. Banks that collect deposits and grant credit found new opportunities to change the structure of their balance sheets that no longer consist of only deposits and loans, but also by securities. Following the above, we were interested in the transformation of banking activity and the emergence of new forms of banking intermediation i.e. marketization of banking.

This article is based on four axes:

The first will focus on developing an understanding of new roles played by banks through the perspective of recent bank intermediation.

The second axis is trying to analyze the performance of the Tunisian banking sector called upon to deal with the changes increased banking activities generated by the liberalization of the economy and its gradual integration into the economic world.

The third is to specify the components of the current banking system in order to adjust our analysis to the Tunisian context. In the end, the final chapter raises the effects of the new orientation of banking, namely the marketization of banking, on the performance of the Tunisian banks. 


\section{New Forms of Bank Intermediation}

Financial intermediaries include all establishments whose primary function is to facilitate the adjustment between demand, and the supply of loanable background of economic agents.

These demands and offers reflect the needs and funding capacity in the immediate future.

Following this logic, banks are financial intermediaries whose purpose is reduced to raise cash from investors (mainly households) to lend them to others (including businesses).

Studies of U.S. commercial banks by several researchers, such as Allen and Santomero (2001), Rajan (1998), showed that these mutations have to regulate their environment by developing new activities and services related to financial markets.

For Lagoutte (2002), banks tend to combine traditional forms of intermediation, relating to collecting deposits and granting loans to new bodies that result in an overlap between bank and market.

\subsection{Securitization of Bank Balance Sheets}

This means that banks finance a growing economy by buying securities from non-financial agents (e.g. treasury bills), and collect a growing share of their resources by issuing securities themselves (bonds, certificates of deposit, etc.).

This phenomenon appeared in the U.S. in the $70 \mathrm{~s}$ as part of the growth of the mortgage market, and securitization has grown strongly in Europe since the late 90s.

Securitization is a financial technique that transforms illiquid assets, that is to say for which there is no real market, into readily marketable securities such as bonds. Generally, according to Sebastian Praicheux (2009), this technique is used to transfer to investors of financial assets such as receivables, turning them into financial securities issued on the capital market. Securitization is an institution out of its heritage assets by selling them as securities for purposes of funding and / or risk transfer.

In this context, DALEY (2001) found that securities portfolios are becoming increasingly important resulting in a change and distortion in the balance sheet structure of French banks.

This evolution of the balance sheet structure was characterized by a significant expansion of the outstanding shares, bonds and other securities with a higher rate mobilization (the financing as a total percentage of financing by credits and titles). Daley (2001) considered that this phenomenon can only be the direct result of increased competitive pressures following the movement of market liberalization.

According to Christian Bialés (2010) "Securitization" or securitization of balance sheets, helps financial officers by an increasing share in their statement of operations with securities for support. This means that they occur at the same time, in more and more markets, hence already mentioned the phenomenon of institutionalization of the markets. (This has also had a special significance in France follows the remarkable development of UCITS). Securitization is reflected first in the asset, by an increased importance of the portfolio. This investment portfolio consists, more precisely, of three "sub-portfolios": that transaction, the largest, which corresponds to securities whose holding, is less than six months, the investment (detention until the end and cover market risks) and investment (holding variable duration and no coverage of market risks).

\subsection{Marketization of Bank Balance Sheets}

Marketization has allowed banks to diversify and increase their funding opportunities, while promoting their integration into the financial system. She also had the effect of allowing banks to align their financial conditions to the stock markets. However, according Tanimoune Ary (2011), it also weakens the banking intermediaries by making them more vulnerable to financial market shocks. Notably, in the United States, marketization has made the posts of bank balance sheets more sensitive to stock market fluctuations; not only have the costs of resources have become more uncertain, but also investment returns operated at variable rates. The increased competition has forced banks to offer new products. Indeed, marketization is to align the lending rates of banks with interest rate markets, and generally results in lower margins for bank profits. Banks try to tailor their offerings to the needs of their customers by offering new products, that is to say that banks offer more favorable borrowing terms than before, hence the reduction of interest rates is considered the goal of market development bank financing.

According Uzunidis and Laperche (2003), marketization is often synonymous in the minds and attitudes of political ideologues and liberals, with modernization. The new global economy would be the product of scientific and technological progress.

This process is a re-regulation of the liberal public sector from the late 1970s and the political choices of the 
Thatcher governments in Britain, and Reagan in the United States.

In this context, Nekhili (2007) noted that the French capital market had experienced, in the early eighties, an important development leading to marketization jobs and banking resources.

According to Christian Biales (2010), marketization taken in its narrow sense, refers to banking terms, debit and credit, and to the extent that, as a result of competition from financial markets to the agents, they this inevitably had to adapt accordingly by aligning their rates on market prices.

\subsection{Development of Off-Balance Sheet Operations}

The off-balance sheet of banks is a set of accounts attached to the balance sheet for tracing the future commitments. It records in particular:

- Transactions in securities (to be received or delivered).

- Forward transactions in foreign currency (currencies to be received or delivered).

- The derivative transactions (such as swaps, futures, and options, etc.). In banks, the technique of off-balance sheet management has assumed greater importance since the 1990s. So the development of off-balance sheet transactions is essentially reflected by the increase in futures trading, in fact it is the hedging of currency and interest rates which is the original reason why banks have embarked on markets derivatives. However, the motivation of banks is not limited to protection against the risk but mostly they want to increase their intervention in the derivatives market.

On the other hand, the regulatory environment has evolved to reflect the increased risk of off-balance generated by these activities.

Thus, successive agreements Basel (Cooke radio), and now Basel II, have been transposed, or are being transposed into national laws forcing them to build up reserves in equity in proportion to their liabilities.

In this context, Edwards and Mishkin (1995) noted that following the decline of their traditional business of collecting deposits and granting of credit, commercial banks have sought new American businesses that are more profitable, significantly affecting their off-balance sheet.

\subsection{The Development of Market Intermediation}

Banks play an increasingly active in the capital market:

-They are the main providers of capital in a fund product market. -They have a function of financial engineering on behalf of big business to allow them access to capital markets (provide assistance, advice, etc.).

-They have much control of securities issued by the State.

-They exercise the functions of market makers by providing liquidity and underwriters of the securities (directly or via mutual funds).

So on the capital market, banks act as intermediaries for stock exchange transactions and advising clients as to their securities transactions. Hence, except for deposits, banks offer their customers investment in stocks and bonds. Customers can send their orders to the bank and the bank monitor its execution. The experts are trying to attend to the bank's client advice. The bank is also responsible for issuing and managing securities and IPOs.

In this context, Allen and Santomero (2001) explained the orientation of banks to market operations. In fact, the traditional activity of banks has changed. Banks that collect deposits and grant credits found new opportunities to change the structure of their balance sheets that are no longer simply deposits and loans, but also securities.

Allen and Santomero (1998) point out that it should be noted that the importance of market intermediation is assessed through the part played by the banking income, excluding intermediation margin. This is why, in recent years, U.S. banks have developed an operations intermediation market. 


\section{Bank Performance}

Performance could be interpreted differently, depending on the scope of the study which it is subject. A multitude of research attests to the development of theories and values relating to the definition and measurement of performance.

\subsection{Determinants of Bank Performance}

The determinants of bank performance have been the subject of several empirical studies, which include, for example, studies by C. Robert (2004) on the macroeconomic determinants of bank financial performance in Singapore; G. Stefan , P. Wensheng and S. Chang (2004) who examined "The determinants of performance of banks in Hong Kong"; J. Guorong T. Nancy and S. Angela (2003) who studied "The determinants of the profitability of banks in Hong Kong "; Tanasser (2003) who presented an analysis of the determinants of the profitability of banks in the countries of the Economic and Monetary Union of West Africa (UEMOA); M. Bashir (2000) who studied, through eight Middle Eastern countries "determinants of performance and profitability of Islamic banks'; Dminiguc-Kunt and Huzinga (1999) showed that, in their study of 80 developed and developing, that the differences in interest margins, measuring performance and profitability bank, between banks reflect a variety of determinants.

These studies suggest that these determinants can be grouped into two main categories:

The internal determinants and external determinants of bank performance. Among the internal factors, we include the impact of human capital, the impact of financial resources, asset quality, management quality, and so on.

We use these internal determinants, in addition to external determinants of bank performance such as store size, scale economies, the banking environment, economies of scale or scope, etc.

\subsection{The Main Dimensions of Bank Performance}

The analysis of bank performance is based on two main dimensions that are risk and bank profit.

\subsubsection{Banking Risks}

Risk can be defined as a potential danger that is, more or less, predictable. Specifically, Bessis (1995) defines risk as "the uncertainty surrounding the results and losses that may occur when environmental changes are adverse." The characteristic of risk is the uncertainty of a temporal event with a certain probability to occur and to embarrass the bank. Risk is inherent in the banking sector and is the source of potential instability of its results.

Risk is different in the banking sector, for its multiplicity and its multidimensional character cannot be measured by one indicator. The various risks that may be incurred by a bank, under all the operations performed, whether they are commercial operations or market transactions, can be presented in two major groups, financial risk and non-financial risk.

There are 6 banking risks of a financial nature as against the risk of party, interest rate risk, liquidity risk, market risk, currency risk and credit risk. Risks of a financial nature referred to above are, in addition other non-financial risks are operational risk and business risk.

\subsubsection{The Bank Profit}

The first measure of bank profit is the net income from which several indicators are constructed to measure the financial performance of banks. Bank profits depend on their ability to create new sources of income, changes in interest rates, trends shown by their non-performing loans and their ability to control costs.

As with all financial institutions, the main function of banks is to channel the surplus capital of individuals, organizations and governments who wish to use them, which is why they are called financial intermediaries.

\section{The Banking Sector in Tunisia}

The banking sector in Tunisia is to show a significant change. In a protected area and closed to open an actor, developed and dynamic in the Tunisian economy. This fits into a context of globalization of financial services increasingly permeated by competition and the further modernization of international financial institutions. The Tunisian banking system has continued to grow in response to environmental change and through the reform of capital markets, redefining the banking and bank restructuring in order to consolidate the sector, improve the quality assets, stabilize the portfolio of nonperforming loans and face lower interest rates and weak economic activity.

This section will be devoted to the study of the banking sector in Tunisia, explaining at first some characteristics of the banking system. In a second step, we will address the refurbishment of the legal framework of the banking 
profession. Finally, the last part of our paper will present the actual architecture of the Tunisian banking system.

\subsection{The Renovation of the Legal Framework of the Banking System}

The new law regulating the banking industry has several key components that address the principle of universality and implementation of mechanisms which can be described as safe.

\subsubsection{The Principle of Universality}

Banking reform of 10 July 2001 abolished the distinction between deposit banks and development banks in favor of the principle of universal banking or banks that do everything. The law $n{ }^{\circ} 2001-65$ of 10 July 2001 organizes the banking system, on the principle that universality allows banks to perform all banking operations. The new law applies to credit institutions, which may be in the form of banks or financial institutions operating in Tunisia, with the exception of mixed development banks that operate under agreements, as it does not apply to offshore banks that are governed by the law 85-108 of 6 December 1985. It is considered a credit institution, a corporation that carries on as usual profession, receiving deposits from the public regardless of the duration and form of exercise as an intermediary, foreign exchange and available to the customer and managing means of payment.

\subsubsection{The Security Mechanisms}

Law No. 2001-65 of 10 July 2001 aims to strengthen four security mechanisms:

*Strengthening the internal audit structure by determining the responsibilities of its structure, which was established in Law No. 67-51, but has been largely marginalized in the organizational chart of the banks? *Moralizing increasingly commercial relationships that businesses have with the bank, its directors and officers.

* Requiring directors and officers of the bank protocol for following bids: collect prior authorization of the board for any agreement with the bank and not within the ordinary course of business.

*To inform the Board of Directors of the bank and the Central Bank of Tunisia of any other transaction that would have initiated in the ongoing operations of the bank.

*Control procedures provisional administration and liquidation.

*The institution of mechanisms for recovery and liquidation apply in case of difficulties of a credit institution operating under the control of monetary authorities.

According to the investment bank of Tunisia, the deregulation of the activity is a framework of incentives for financial innovation and, therefore, the introduction of competition and diversification while the introduction of security mechanisms is the first seeds of bank accountability face of rising risk of bankruptcy and to ensure transparency and guarantee the rights of other third-party (depositor creditors, investors) at the sector level.

\subsection{Current Architecture of the Tunisian Banking System}

In light of the new law No. 2001-65 of July 10, 2001, the banking system is essentially composed of central bank credit institutions.

\subsubsection{The Central Bank of Tunisia (BCT)}

The Central Bank of Tunisia, created by Law No. 58-90 of September 19, 1958, was created to be both the agency issuing the currency manually, the bankers' bank, the bank of the State, the public service of centralized management of currency, the supervisory body of banks as it defines the business rules that institutions must comply under penalty of jeopardizing the institution and deposits at the end the agent of monetary policy decided by the government. In addition to public service missions, the BCT's mission is to defend the general value of money, ensure its stability and by daily monitoring of monetary indicators.

\subsubsection{Credit Institutions}

Credit institutions in operation are made by banks and financial institutions:

* The banking system in Tunisia includes 21 commercial banks. In 2005, its structure changed dramatically following the creation of a new bank called "Bank of Financing Small and Medium Enterprises", the privatization of the South Bank, now called Attijari Bank, and the changing status of banks development, STUSID, BTL, and BTK TQB into universal banks. In January 2008, and as part of the restructuring of the banking sector, there has been the privatization of the Tunisian-Kuwaiti Bank 6 by the sale of $60 \%$ of its shares in favor of the finance company "OCEOR" subsidiary of the French "Caisse d'Epargne ". In Tunisia, the banking sector is mainly composed of private banks and mixed capital ( $70 \%)$, but the state-owned banks play a dominant role in financing the economy. Of the 20 banks that count the Tunisian banking system, 11 banks are listed on the Tunisia Stock Exchange. The Tunisian banking sector is characterized by a high number of banks in relation to its population of 
10.6 million: 21 banks (including 11 listed), and half of which are very small. Thus, a total of 52 billion dinars balance at the end of 2010, 11 of the 21 banks show a cumulative total asset of 4.3 billion dinars only.

* Financial institutions include merchant banks, financial institutions, leasing and factoring financial institutions.

\section{Empirical Evidences on the Impact of Marketization of Banking Operations on the Performance of Tunisian Banks}

\subsection{Analytical Framework and Research Methodology}

This present study will attempt to provide answers to the problems already advanced at the beginning of our work.

For this purpose, it is necessary to recall the various questions connected with it, so that the objectives that we want to achieve.

\subsubsection{The Analytical Framework}

We will try, in this chapter, to test the following hypothesis: HYPOTHESIS: The marketization of bank balance sheets generally results in lower margins for bank profits. In order to evaluate the impact of the marketization of banking on the performance of Tunisian banks, we will proceed to verify the following hypotheses derived from the central assumption of our analysis: Molyneux and Thornton (1992) studied the determinants of bank performance in some countries. Their study covers 18 European countries during the period 1986 to 1989 . They put a positive relationship between bank profitability and the level of interest rates in each country, that is to say more than the money market rate increases more than bank performance increases. So it makes sense to verify the findings of these studies by the following hypothesis: H1: The money market rate has a positive impact on the performance of the banks: The more it increases, the more performance increases. Barth and Alii (1997) report, in the case of 19 developed countries which have established that the deposits collected and the existence of explicit deposit insurance, have no significant impact on the performance of bank stocks.

Secondly, Bikram (2003) explains that loans by public banks positively and significantly influence bank profitability because they benefit. These explanations may well apply to the Tunisian case. Indeed, the BNA and STB are the first incorporated banks in Tunisia. In addition, they benefit from their leadership positions in credit for the broad economic sectors such as habitats and structures in BH and the agriculture and fisheries to the BNA.

Indeed, Dinç (2005) shows empirically that the government-owned banks increased their loans from private banks during election years.

In addition, Sapienza (2004) compares the interest rate charged to companies borrowing from private banks, and those Italian borrowing from state banks. This comparison shows that they charge interest rates lower than those charged by private banks. The author suggests that this difference can be explained by the political argument of state banks.

Pi and Timme (1993) reveal in their investigation of large U.S. commercial banks during the years 1988-1990, more than the credits granted to customers' increases, the risk of loss increases. Their findings tend to predict a negative impact on the performance of banks.

Therefore, the following assumptions must be true: H2: The higher the percentage of deposits increases, the performance of banks fell. H3: The higher the percentage of loans granted to customers increases, the performance of banks fell. Bassett and Brady (2001) note that banks of small sizes (from their assets) are more successful than large or "giant" ones, based on return on equity and asset management. They said the reason is that small banks have higher rates of returns on their loans.

Furthermore, we find that the size of the bank has a negative and statistically significant impact on accounting performance thus corroborating the results of Spong et al (1996) and Berger and Bonaccorsi of Patti (2003). In Tunisia, and SB Nasseur M.Gaoied (2001) have introduced size, measured by total assets, among the explanatory variables on the performance of Tunisian deposit banks and their results do not confirm the significance of size in explaining bank performance.

So it makes sense to verify the findings of these studies with the following hypothesis: H4: The size of banks has a negative impact on the performance of banks: The more it increases, the more performance decreases. Fernandez and Arrondo (2002), and Bassett and Brady (2001), note that the debt ratio is negatively and significantly affect bank performance due to financial burdens which reduce net income.

We then set the following hypothesis: H5: The debt ratio has a negative impact on the performance of banks. 


\subsubsection{Description of Research Methodology}

The objective of this chapter is to analyze the activity of 10 Tunisian banks over a period of 13 years (1997-2009). Our empirical analysis is based on a study of bank performance through an analysis by an indicator (GNP) and ratios (ROA, ROE).

To better use of our database, the empirical technique we used is the technique of panel data. This technique allows us to exploit the temporal dimension (13yrs) and spatial (10 banks).

The basic equation to estimate is:

$$
\Pi_{i t}=C+\sum_{k=1}^{k=K} \beta_{K} X_{i t}^{K}+\varepsilon_{i t}
$$

With:

$\Pi_{i t}$ : The measure of the performance of bank i at time t. $\Pi_{i t}$ : corresponds to three performance measures namely GNP, ROA and ROE. $C$ : is a constant term. $\varepsilon_{i t}$ : Is the residual error term white noise. $\mathrm{X}_{\mathrm{it}}$ : is the group of explanatory variables, it includes an effect and an impact rate structure. The equation becomes:

$$
\Pi_{i t}=C+\beta_{1} D E+\beta_{2} C R+\beta_{3} D E B F+\beta_{4} C E B F+\beta_{5} D U M+\beta_{6} T M M+\beta_{7} L N T A+\beta_{8} E N D+\varepsilon_{i t}
$$

With: t: 1997-2009; i: i Bank

$$
\Pi_{i t}: \text { GNP, ROA, ROE }
$$

\subsection{Description of Variables}

\subsubsection{The Dependent Variables}

-The net banking income (NBI): Net banking is equivalent to the turnover of a business classic. It measures the specific contribution of the institution to national wealth. It is what remains when touched everyone's salary and other expenses, creditors and tax authorities have been resolved.

It is the equivalent of the value added terms of traditional financial analysis (Shaked, Michel and Lery 1998).

-The ratio of return on equity or "Return on Equity" (ROE)

This ratio is measured by the ratio of profit (or benefit) and net equity. It is mainly used in the evaluation of bank performance; this ratio measures the ability of the beneficiary bank to see returns on investments. It also indicates the return on capital invested by shareholders. However, the disadvantage is that this ratio can give a biased picture of profitability since a high ratio may result from a low level of capital. This ratio was chosen by Holderness and Sheehan (1988) and Lauterbach and Schreiber (2002). • The ratio of return on total assets or "Return on Assets" (ROA)

The dependent variable chosento explain bank profitability is the Tunisian economic profitability, is ROA. This is a quantitative variable that is expressed by the rate of net income to total assets. This is the return on assets. It expresses in general economic profitability. Its main advantage is that it covers all activities of the bank. Its main drawback is that it places all of the assets on the same level of risk, while the risks associated with components of the total assets are different. In addition, it neglects the off-balance sheet activities are being scaled up in banking (Densetz and Saidenberg, 1999).

ROA has been used by many authors such as Barro (1990), and Angbazo Narayanan (1997), Yan (1998) and Hirschey (1999).

\subsubsection{The Explanatory Variables}

This section is devoted to explaining the performance of Tunisian banks by reference to a rate effect and structure effect.

The variables that may reflect the rates are either the market rate (TMM, TMO) or the borrowing rate (TBB). The variable rate that we considered is the MMR since it is regularly published by the BCT.

The second set of exogenous variables, which made the structure effect, reflects the deformation of the balance sheets. This may be the ratio of customer deposits to total assets, or the ratio of customer loans to total assets, or the ratio of deposits and assets of banks and financial institutions in total assets, from credit report on banking and financial institutions in total assets.

Because of the different phases of economic reform and especially the Tunisian banking reform of July 10, 2001, 
we have considered regulatory factors (change in banking regulations). This dummy variable (DUM) is likely to affect the performance of Tunisian banks.

We will use here, as a control variable, the size of the bank and the debt ratio of the bank.

Bank size, in terms of total assets, is used to assess whether banks are more profitable, since they are exposed to greater risk diversification than smaller banks.

Moreover, small banks have an incentive to grow to increase their competitiveness while, conversely, those of large sizes have no incentive to grow. In our case, we use the Log (Total Assets) as a measure of the size of the Tunisian banks.

The debt ratio is measured by the ratio of total debt to total assets. This is a classic measure of leverage that was used by several authors such Agrawal and Knoeber (1996), Mak and Ong (1999) and Fernandez and Arrondo (2002).

Table 1. Explanatory variables

\begin{tabular}{cc}
\hline Variables & Meaning \\
\hline DE & Report of customer deposits to total assets \\
CR & Report of customer loans to total assets \\
DEBF & Report of the deposits and assets of banks and financial institutions in total assets \\
CEBF & Report credits on banks and financial institutions in total assets \\
DUM & Regulatory factors that may affect the performance of the Tunisian banks. \\
TMM & The annual rate of money market, published regularly by the BCT \\
LNTA & Store Size: Natural logarithm of book value of total assets. \\
TEND & Debt ratio of bank: total debt / accounting value of total assets. \\
\hline
\end{tabular}

\subsection{Descriptive Statistics and Correlations between Variables}

\subsubsection{Descriptive Statistics}

Descriptive statistics is the instrument that gives a sense, an expression for the required information. It reveals the essential characteristics of a data set for a simplified picture of reality.

Table 2. Statistiques descriptive

\begin{tabular}{cccccc}
\hline Variable & Mean & Maximum & Minimum & $\begin{array}{c}\text { Standard } \\
\text { Deviation }\end{array}$ & observations \\
\hline PNB & 89180.20 & 212066.00 & 30940.00 & 37504.26 & 130 \\
ROA & 0.008144 & 0.022037 & -0.081303 & 0.010321 & 130 \\
ROE & 0.077580 & 0.207392 & -1.764798 & 0.192608 & 130 \\
DE & 0.682300 & 0.840000 & 0.400000 & 0.096178 & 130 \\
CR & 0.703500 & 0.830000 & 0.030000 & 0.112729 & 130 \\
DEBF & 0.044400 & 0.153000 & 0.005000 & 0.029578 & 130 \\
CEBF & 0.090230 & 0.670000 & 0.014000 & 0.081087 & 130 \\
TMM & 5.796490 & 6.880200 & 5.000000 & 0.671457 & 130 \\
DUM & 0.500000 & 1.000000 & 0.000000 & 0.502519 & 130 \\
LNTA & 14.45320 & 15.36000 & 13.54000 & 0.472955 & 130 \\
TEND & 0.856866 & 0.953931 & 0.624834 & 0.088484 & 130 \\
\hline
\end{tabular}


The table also shows considerable variation in GNP (GNP GNP min and max 30940212 066) which suggests the emergence of a new conception of the net proceeds in Tunisia. According to Table No. 2, there is also a variation in the ratio of customer deposits to total assets $(\mathrm{DE}=0.4 \mathrm{~min}$; OF mean $=0.68$; OF $\max =0.84)$ suggesting that credit interest rates are motivating for agents to funding capacity.

On the other hand, we also note a considerable variation in the ratio of customer loans to total assets $(\mathrm{CR}=0.03$ $\min$; Avg $\mathrm{CR}=0.7, \mathrm{CR} \max =0.83$ ) indicates that it rates are fully liberalized interest expense from the November 29, 1996 for all credit except those relating to loans made by the Tunisian Solidarity Bank.

\subsubsection{Correlations}

Table 3. Correlations of variables

\begin{tabular}{ccccccccc}
\hline & CEBF & DEBF & DE & CR & TMM & DUM & LNTA & TEND \\
\hline CEBF & 1.000000 & -0.057497 & 0.085117 & -0.432997 & 0.110100 & -0.183563 & -0.171868 & 0.020552 \\
DEBF & -0.057497 & 1.000000 & -0.012186 & 0.164271 & 0.168379 & -0.254842 & -0.358003 & 0.015700 \\
DE & 0.085117 & -0.012186 & 1.000000 & -0.100702 & -0.483047 & 0.308268 & -0.098957 & 0.351718 \\
CR & -0.432998 & 0.164272 & -0.100703 & 1.000000 & -0.329400 & 0.276784 & 0.187938 & 0.253777 \\
TMM & 0.110100 & 0.168379 & -0.483047 & -0.329400 & 1.000000 & -0.454187 & -0.393407 & -0.391368 \\
DUM & -0.183564 & -0.254843 & 0.308268 & 0.276784 & -0.454187 & 1.000000 & 0.368052 & 0.421834 \\
LNTA & -0.171869 & -0.358003 & -0.098958 & 0.187938 & -0.393407 & 0.368052 & 1.000000 & 0.285122 \\
TEND & 0.020552 & 0.015701 & 0.351718 & 0.253777 & -0.391368 & 0.421834 & 0.285122 & 1.000000 \\
\hline
\end{tabular}

After the analysis in Table No. 3, we note that the level of correlation between variables is low. So we see the lack of a correlation between the explanatory variables.

\subsection{Study of Stationarity: Unit Root Tests}

One way to ensure the stationarity of individual data is to apply the unit root test (ADF). The test we use is the test of Im, Pesaran and Shin (IPS). This test has properties that are simpler, and is characterized by a greater power than the test of Levin Lin (LL).

The model to be estimated in order to study the stationarity is as follows:

$$
y_{i t}=\alpha_{i}+\left(1-\rho_{i}\right) y_{i, t-1}+\sum_{i=1} \varphi_{i j} \Delta y_{i t-j}+\varepsilon_{i t}
$$

This is to test:

$$
\begin{aligned}
& H_{0}: \rho_{i}=1 ; \forall \mathrm{i}=1, . ., \mathrm{N} \\
& H_{a}: \rho_{i}<0 ; \forall \mathrm{i}=1 ; 2, . ., \mathrm{N} 1 \\
& \rho_{i}=0 ; \quad \forall \mathrm{i}=\mathrm{N} 1+1 ; \mathrm{N} 1+2, . ., \mathrm{N}
\end{aligned}
$$

The estimation results on the 5.0 software EVIEWS included in the following table: 
Table 4. Unit root test

\begin{tabular}{ccc}
\hline Variables & Calculated-t & Prob \\
\hline PNB & 1,6348 & 0,7248 \\
ROA & 2,0264 & 0,3326 \\
ROE & 1,9033 & 0,4839 \\
DE & 3,8450 & 0,0000 \\
CR & $-3,675$ & 0,0001 \\
DEBF & $-2,7045$ & 0,1099 \\
CEBF & $-2,937$ & 0,0939 \\
TMM & $-2,4392$ & 0,1264 \\
LNTA & 3,0261 & 0,0867 \\
TEND & $-4,835$ & 0,000 \\
\hline
\end{tabular}

It follows that the probabilities of the variables are greater than 0.05 except for variable DE, CR, IS. This indicates that one can accept the null hypothesis of nonstationarity at $95 \%$ for the GNP series, ROA, ROE, DEBF, CEBF, TMM, LNTA and we can reject this hypothesis for the variables DE, CR, IS. Data DE, CR, TEND are stationary as shown in Table 4. The variables are not integrated to order 1: These data are stationary in levels and are I (0).

Generally, tests Augmented Dickey-Fuller on GNP variables, ROA, ROE, DEBF, CEBF, TMM, and LNTA to accept the null hypothesis of nonstationarity.

In the second step, we move to test the stationarity of the variables in first difference.

The ADF test leads us to reject the null hypothesis of nonstationarity for the variables CEBF, TMM, LNTA.

The assumption of stationarity is accepted at a $5 \%$ threshold for these first-differenced variables (variables embedded in ordre1).

In the third step, we move to test the stationarity of the differenced variables remains secondary. The assumption of stationarity is accepted at a threshold of $5 \%$ for GNP, ROA, ROE, DEBF difference in secondary. Knowing also that these variables integrated of order 1 and 2 may provide trend movements so that their linear combinations and their trend components offset each other to provide a stationary series.

\subsection{Econometric Specification}

In this section we will study the impact of the marketization of banking on the performance of Tunisian banks using a multiple regression model and econometric tools.

Econometrically, testing specifications revert to determine if one is to assume that the theoretical model studied is exactly the same for all banks, or the contrary if there are specific features of each bank.

To validate the model specification, two tests are critical: Fisher's test to verify the existence of an individual effect and the Haussman test that identifies the nature of these effects.

The models constructed regression variables affect the marketability of banking and the control variables on the performance of banks.

To test the homogeneity of the Panel, we applied the test of Hsiao (1986). Hsiao of the F-statistic follows an F distribution with $(\mathrm{K}+1)(\mathrm{N}-1)$ and $\mathrm{NT}-\mathrm{N}(\mathrm{K}+1)$ degrees of freedom and is written as follows:

$$
F=\frac{\left(S C R_{b}-S C R_{a}\right) /(N-1)(K+1)}{S C R_{a} / N T-N(K+1)}
$$

$S C R_{b}$ : The sum of squared residuals without fixed effects.

$S C R_{a}$ : The sum of squared residuals with fixed individual effects.

$\mathrm{N}$ : The number of banks $\rightarrow \mathrm{N}=10$

$\mathrm{T}$ : The number of years $\rightarrow \mathrm{T}=13$

$\mathrm{K}$ : The number of explanatory variables and control $\rightarrow \mathrm{K}=8$ 
If $F$ is above the theoretical $\alpha \%$ then we reject the null hypothesis of homogeneity. If it is below this threshold, we accept H0. In this case, calculated $\mathrm{F}$ is significantly lower than statistical $\mathrm{F}$ which is equal to 2.9.

The test of Hsiao (1986) allows us to accept the Panel's perfectly homogeneous structure. It then adopted the method of least square ordinary or generalized.

\subsection{Regression Results}

\subsubsection{Impact of Marketization on the Performance of Banks Measured by GNP}

To measure the influence of marketization banking on the performance of Tunisian banks, we use the following specification is a regression of the variables of marketization on the Net Banking Income (GNI):

$$
P N B=\alpha+\beta_{1} D E+\beta_{2} C R+\beta_{3} D E B F+\beta_{4} C E B F+\beta_{5} T M M+\beta_{6} D U M+\beta_{7} L N T A+\beta_{8} T E N D+\varepsilon_{i}
$$

To test this model, then we adopt the method of ordinary least-square using the software "Eviews 5":

Table 5. Regression results of marketization on the performance of banks measured by GNP Dependent Variable: PNB

\begin{tabular}{cccc}
\hline Variable & Coefficient & Std. Error & t-Statistic \\
\hline C & -101.2669 & 98.97781 & 10.23128 \\
DE & 6.907090 & 2.640774 & 2.615555 \\
CR & 23.63863 & 20.30447 & 2.164208 \\
CEBF & 3.101427 & 2.534640 & 2.013617 \\
DEBF & 16.14670 & 0.696871 & 0.231664 \\
TMM & -57.72583 & 6.025659 & 0.095468 \\
DUM & -3.301263 & 0.627767 & 5.025924 \\
LNTA & 72.95666 & 4.851133 & 15.03910 \\
TEND & -17.38279 & 0.381363 & 0.529743 \\
R-squared & 0.792518 & & \\
Adjusted R-squared & 0.774278 & & \\
\hline
\end{tabular}

The regression results show that the money market rate (TMM) has a negative and insignificant impact on the performance of Tunisian banks. Thus, the hypothesis H1 is invalidated.

This result is consistent with literature stating that the bank credit in Tunisia continues to be the main source of financing non-financial agents. That is to say, when the interest rate increases, the use of credit decreases and this has, accordingly, reduced bank profits. Regarding the presence of deposits, the results show the positive impact of this variable on the performance of Tunisian deposit banks. Therefore, the hypothesis $\mathrm{H} 2$ is reversed.

Similarly, regarding the presence of funding, the regression table shows that this variable has a positive and statistically significant impact on the performance of Tunisian banks. Thus, hypothesis $\mathrm{H} 3$ is rejected.

Even after the financial reforms, the Tunisian financial system remains highly intermediated, although balance sheet analysis and composition of net banking has shown that there is appearance of new professions within the Tunisian deposit banks. The review of bank balance sheets and interpretation of components of net banking have shown that the activity of intermediation of Tunisian commercial banks is not in decline. They still carry the traditional business of collecting deposits and granting loans.

The regression results also reveal that bank size has a positive and statistically significant impact on the performance of Tunisian banks. Therefore, the hypothesis $\mathrm{H} 4$ is invalidated.

We note that the debt ratio negatively influences the performance of Tunisian banks, so the hypothesis H5 is verified. This is consistent with the results of research conducted by Agrawal and Knoeber (1996), Mak and Ong (1999) and Fernandez and Arrondo (2002), showing that if the coefficient of the TEND variable takes a negative sign, it is possible to explain by the fear of investors when they realize that the debt ratio of banks reached excessive levels. 


\subsubsection{Impact of Marketization on the Performance of Banks Measured by the ROA}

To measure the influence of marketization banking accounting performance, we use the following specification is a regression of the variables of marketization on the Return on Assets:

$$
R O A_{i t}=\alpha+\beta_{1} D E+\beta_{2} C R+\beta_{3} D E B F+\beta_{4} C E B F+\beta_{5} T M M+\beta_{6} D U M+\beta_{7} L N T A+\beta_{8} T E N D+\varepsilon_{i}
$$

To test this model, then we adopt the method of least squares using the software "Eviews 5":

Table 6. Regression results of marketization on the performance of banks measured by the ROA Dependent Variable: ROA

\begin{tabular}{cccc}
\hline Variable & Coefficient & Std. Error & t-Statistic \\
\hline C & 0.113292 & 0.055850 & 2.028505 \\
CEBF & 0.039410 & 0.014302 & 2.705451 \\
DEBF & -0.025436 & 0.039329 & 2.046763 \\
DE & -0.016253 & 0.014901 & 1.990705 \\
CR & 7.026103 & 0.114357 & 0.633888 \\
TMM & -2.904396 & 0.321450 & 0.881237 \\
DUM & 0.063919 & 0.035472 & 2.806515 \\
LNTA & -0.005013 & 0.002737 & 1.831489 \\
TEND & -0.006264 & 0.018516 & 0.338285 \\
R-squared & 0.412775 & & \\
Adjusted R-squared & 0.305107 & & \\
\hline
\end{tabular}

The regression results show that the MMR has a negative and insignificant impact on the performance of Tunisian banks. Thus, the hypothesis H1 is invalidated. Indeed, over the MMR increases, the agents in need of funding are forced to seek informal financing resulting in the development of an unregulated market of credit and therefore a segmentation of the financial system. This idea was adapted by Fry (1997).

Regarding the presence of deposits, the results show they have a negative impact on accounting performance. Therefore, the hypothesis $\mathrm{H} 2$ is confirmed. Similarly, regarding the presence of funding, the regression table shows that this variable has a positive and statistically significant impact on the performance of Tunisian banks. Thus, hypothesis $\mathrm{H} 3$ is rejected.

Indeed, the examination of balance sheets shows that the intermediation activity of Tunisian banks remains the main source of bank profits; they still carry the traditional business of collecting deposits and granting loans. The regression results show that rising bank size has a negative and statistically insignificant effect on the performance of Tunisian banks. Therefore, the hypothesis H4 is confirmed.

This result is consistent with literature stating that more the greater the increases in bank size, the more performance decreases (Spong et al (1996); Berger and Bonaccorsi di Patti (2003)).

Finally, these results allow us to observe the negative impact of the presence of IS performance bank accounting, so the hypothesis H5 is verified. This is consistent with results of Mak and Ong (1999), and Agrawal and Knoeber (1996), which state that the debt ratio negatively influences the performance of banks.

5.6.3 Impact of Marketization on the Performance of Banks as Measured by ROE

To measure the influence of marketization banking accounting performance, we use the following specification is a regression of the variables of marketization on the Return on Equity:

$$
R O E_{i t}=\alpha+\beta_{1} D E+\beta_{2} C R+\beta_{3} D E B F+\beta_{4} C E B F+\beta_{5} T M M+\beta_{6} D U M+\beta_{7} L N T A+\beta_{8} T E N D+\varepsilon_{i}
$$


To test this model, then we adopt the method of least squares using the software "Eviews 5":

Table 7. Regression results of marketization on the performance of banks as measured by ROE

\begin{tabular}{cccc}
\hline Variable & Coefficient & Std. Error & t-Statistic \\
\hline C & 0.499132 & 1.072632 & 0.465334 \\
CEBF & 0.080658 & 0.275844 & 2.921405 \\
DEBF & -0.105095 & 0.757667 & 3.871208 \\
DE & -0.119069 & 0.286704 & -0.415304 \\
CR & 6.162364 & 0.219125 & 2.851410 \\
TMM & 0.003597 & 0.065377 & 0.055014 \\
DUM & -1.206247 & 0.068141 & 2.062204 \\
LNTA & -0.015644 & 0.052635 & 4.972121 \\
TEND & -0.172604 & 0.355940 & -0.484925 \\
R-squared & 0.731039 & & \\
Adjusted R-squared & 0.648452 & & \\
\hline
\end{tabular}

The regression results show that the MMR has a positive and statistically insignificant effect on the accounting performance of Tunisian banks. Thus, the hypothesis $\mathrm{H} 1$ is verified.

This result is consistent with literature stating that the increase in MMR encourages officers with funding capacity to invest their funds in banks, and this result in increased bank profits.

Regarding the presence of deposits, the results show the negative impact and insignificant effect of this variable on the performance of Tunisian deposit banks.

Therefore, the hypothesis $\mathrm{H} 2$ is confirmed and this is identical to the experience of Barth and aluminum (1997), in the case of 19 developed countries. These authors found that the deposits collected and the existence of deposit insurance have no significant impact on bank performance.

Similarly, regarding the presence of funding and the regression table shows that this variable has a positive and statistically significant impact on the performance of Tunisian banks. Thus, hypothesis $\mathrm{H} 3$ is reversed.

The regression results indicate that the size of banks has a negative and statistically significant impact on the performance of Tunisian banks. Therefore, the hypothesis $\mathrm{H} 4$ holds. This result is consistent with literature stating that more than the size of banks increases, the more performance decreases (Spong et al (1996), Berger and Bonaccorsi di Patti (2003)).

Finally, we note that the debt ratio negatively influences the performance of Tunisian banks, so the hypothesis H5 is confirmed. This is consistent with the results of research conducted by Agrawal and Knoeber (1996), Mak and Ong (1999) and Fermandez and Arrondo (2002), which stipulate that if the coefficient of the TEND variable takes a negative sign, it is possible to explain by the fear of investors when they realize that the debt ratio of banks reached excessive levels.

\section{Conclusion}

The Tunisian banking and financial system has pledged to take on the heavy responsibility to sustain and support the implementation of the restructuring, modernization and financial liberalization, since 1986. Indeed, the banking system must adapt to the profound changes that are shaping the spirit of the national and global financial landscape, and should have more responsibility in dealing with increased competition by diversifying their products and services.

One can say that the development of theories of intermediation was needed to understand the changes of various banking systems. In reality, the place of intermediaries, and especially banks, has grown not only on the credit market, but also on all financial markets. The range of their activities has greatly expanded by creating new functions. The most important is the marketization of banking.

Therefore, the objective was to measure the impact of the marketisation of banking on the performance of Tunisian banks. 
Indeed, according to analysis performed on a set of ten Tunisian banks, between 1997 and 2009, we found that the money market rate has no significant impact on bank performance, and the deposits and loans positively and significantly influence the performance of Tunisian banks. In light of these results, then we find that in Tunisia, banks have not yet exploited new forms of intermediation. Hence, it is confirmed that the context of traditional intermediation remains, despite reforms and financial liberalization. Banks still carry the traditional business of collecting deposits and granting loans to increase their profit margins bank.

It should be noted that our study was limited to ten banks due to their supremacy in the Tunisian banking sector. It should broaden our field of study to all banks that are now having a considerable weight in the funding of the Tunisian economy. In the end, it should be noted that we tried to find a relationship between short-term banking development and performance of Tunisian banks. In a continuation of our research, we will try to conduct an empirical study on the case of Tunisia, to justify that particular bank financial development can have positive effects on economic growth. For this, we will attempt to test empirically, through analysis of co-integration, the possible existence of a long-term relationship between the variables of economic growth on the one hand, and indicators of banking development on the other part.

\section{References}

Allen, F., \& Santomero, A. M. (2001). What do financial intermediaries do? Journal of Banking and Finance, 25, 271-294. http://dx.doi.org/10.1016/S0378-4266(99)00129-6

Beck, T., Levine, R., \& Loayza, N. (2000). Financial intermediation and Growth: causality and causes. Journal of Monetary Economics, 46, 31-77. http://dx.doi.org/10.1016/S0304-3932(00)00017-9

Bottazzi, L., Rin, M. D., \& Hellmann, T. F. (2004). Active Financial Intermediation: Evidence on the role of organization and Human capital. juillet, Igier working paper 266.

Barth, J. R, Nolle, D. E, Phuniwasana, T., \& Yago, G. (2002). Across country Analysis of the bank supervisory frame work and bank performance. Economic and Policy analysis Working paper, 2, Office of the comptroller of the currency (O.C.C).

Chichti, J. E. (2000). The financial intermediation of banks and insurances. Publication of the official printing office of the Tunisian Republic.

Coval, J., \& Thakor, A. V. (2004). Financial Intermediation as a Beliefs-Bridge between optimists and pessimists. Journal of Financial Economics, Forthcoming.

Daley, N. (2001). The retail banking in France: of the intermediation to the services. Center of Industrial Economy, Paris, (Fèvrier).

Demsetz, H., \& Villalonga, B. (2001). Ownership structure and corporate performance. Journal corporate Finance, 209-233. http://dx.doi.org/10.1016/S0929-1199(01)00020-7

Kertudo, J. (2001). The Financial system in front of the globalization. Edition CFPB.

Lagoutte. (2002). The profitability of banks Britanique in question: theoretical and strategic approach. Thematic Axis: Intermediation and Financial Systems, University of Lille III.

Nekhili, M. (2001). The relation bank-company: international practices of the financial intermediation. Finance and Development in the Maghreb, 27, 35-48.

Payelle, N. (2001). Typology of the financial systems. French exercise books, 301, 15-22.

Paolo Guarda, \& Abdelaziz Rouabah. (1999). Efficiency and Performances of banks in Europe: an analysis stochastic frontier on data of Panel, W.P (CERA).

Praicheux, S. (2009). The reform of the securitization, the critical point of view. Bulletin Joly Bourse, 2, 144.

Saïdane, D. (2001). The bank commercial traditional is in decline. Finance and Development in the Maghreb, 27, 12-34. 